JERZY SOJKA, WARSZAWA

\title{
NAUKA O USPRAWIEDLIWIENIU A WSPÓŁCZESNOŚĆ. PYTANIE O AKTUALIZACJĘ KLUCZOWEGO TEMATU TEOLOGII EWANGELICKIEJ NA PRZYKŁADZIE REFLEKSJI ŚWIATOWEJ FEDERACJI LUTERAŃSKIEJ
}

Wyzwaniem dla refleksji teologicznej każdego kręgu konfesyjnego jest nie tylko jej reakcja wobec nowych problemów, jakich dostarcza nam stale zmieniająca się rzeczywistość, ale także pytanie o to, jak wyrazić kluczowe prawdy stojące u fundamentów danego teologicznego sposobu rozumowania w języku dostępnym dla współczesnych. Przed takim wyzwaniem stoi także teologia ewangelicka. Niewątpliwie jednym z najbardziej kluczowych tematów teologicznych, przesądzającym o jej teologicznym profilu, jest nauka o usprawiedliwieniu jedynie z łaski przez wiarę. To sformułowane przez XVI-wiecznych reformatorów odczytanie biblijnego przesłania o zbawieniu człowieka stawia przed współczesną ewangelicką teologią pytanie o swoją aktualność.

Niniejszy artykuł podejmie próbę ukazania tych odpowiedzi na przykładzie refleksji Światowej Federacji Luterańskiej (ŚFL) - największej międzynarodowej organizacji zrzeszającej Kościoły luterańskie na świecie. Powszechnie znany jest fakt, że temat ten stał się przedmiotem intensywnego dialogu teologicznego między Kościołami członkowskimi ŚFL a Kościołem katolickim, który przyniósł podpisaną w 1999 r. w Augsburgu Wspólna deklarację w sprawie nauki o usprawiedliwieniu. ${ }^{1}$ Nie jest to jednak jedyny dokument poświęcony tej tematyce, jaki w swojej ponad 60-letniej historii przygotowała ŚFL. Po raz pierwszy aktualność nauki o usprawiedliwieniu była przedmiotem refleksji na IV Zgromadzeniu Ogólnym

1 Zob. Deklaracja o usprawiedliwieniu. Historia powstania. Tekst deklaracji. Opinie. Komentarze, Bielsko-Biała 2000. 
w Helsinkach w 1963 r., które odbywało się pod hasłem: „Christus heute/Christ Today” („Chrystus dzisiaj”). ${ }^{2}$ W wyniku prac zgromadzenia oraz późniejszych prac Komisji Teologicznej ŚFL na posiedzeniu w Pullach, ${ }^{3}$ która podsumowała wyniki szerokich konsultacji w trakcie obrad w Helsinkach, ${ }^{4}$ powstał dokument Rechtfertigung heute/Justification today (Usprawiedliwienie dzisiaj). ${ }^{5}$ Drugi z dokumentów powstał w kontekście prac nad wspomnianą już Wspólna deklaracją w sprawie nauki o usprawiedliwieniu. Refleksja nad tym tematem w dialogu ekumenicznym skłoniła ŚFL do podjęcia go ponownie w trakcie studiów w ramach Federacji. W 1998 r. odbyła się poświęcona mu konsultacja teologiczna w Wittenberdze, ${ }^{6}$ której plonem były nie tylko tom studiów nad usprawiedliwieniem w różnych kontekstach przygotowanych przez teologów z różnych luterańskich Kościołów świata, ${ }^{7}$ ale także dokument roboczy pt. Controversy regarding the Contextuality of the Doctrine of Justification. The implications of justification in the world's contexts/Streit um die Kontextualität der Rechtfertigungslehre. Implikationen der Rechtfertigung in den Kontexten der Welt (Spór o kontekstualność nauki o usprawiedliwieniu. Implikacje usprawiedliwienie w kontekstach świata). ${ }^{8}$ Oba dokumenty nie miały charakteru rozstrzygającego

2 J. H. S c h j ø r r i ng i in. (red.), Vom Weltbund zur Gemeinschaft, Hannower 1997, s. 324-330.

3 Zob. W. Tri 11 h a a s, Die Sitzung der Theologischen Kommission in Pullach, Lutherische Rundschau 15(1965) z. 1, s. 60-63.

4 Zob. Bericht der Diskussionsgruppen über die Rechtfertigung, w: Offizieller Bericht der Vierten Vollversammlung des Lutherischen Weltbundes, Helsinki, 30. Juli-11. August 1963, Berlin-Hamburg 1965, s. 480-521.

5 Rechtfertigung heute (Endgültige Fassung des Dokumentes 75), w: tamże, s. 522-529.

6 Zob. W. G re i ve, The significance of justification in the World's context. Towards a new interpretation of the doctrine of justification, LWF Documentation 45/2000, s. 11-21.

7 Justification in the World's Context, tamze = Rechtfertigung in den Kontexten der Welt, tamże.

8 Controversy regarding the Contextuality of the Doctrine of Justification. The implications of justification in the world's contexts, tamże, s. 181-186= Streit 
stanowiska doktrynalnego, były raczej dokumentami roboczymi, które miały dostarczyć impulsu do odnowienia refleksji nad usprawiedliwieniem w luterańskich Kościołach na świecie. Tym samym, nie mając wiążącego charakteru, dobrze dokumentują nieustannie podejmowany trud aktualizacji kluczowego dla luteranizmu tematu teologicznego - usprawiedliwienia.

\section{Pytanie o aktualność usprawiedliwienia}

Dokument Rechtefertigung heute, przygotowany na podstawie dyskusji podjętych na Zgromadzeniu Ogólnym ŚFL w Helsinkach, podzielony został na sześć części. W pierwszej z nich postawiona została diagnoza sytuacji człowieka. Autorzy wskazują w niej, że podstawowym problemem dla aktualności nauki o usprawiedliwieniu jest fakt, że w XVI w. była ona formułowana w kontekście oczywistego pytania: „Jak znajdę łaskawego Boga?” Oczywistość pytania o Boga została współcześnie zastąpiona pytaniami o sens życia człowieka. Człowiek dąży do usprawiedliwienia swojej egzystencji przed sobą i bliźnimi, samodzielnie formułując wzorce, wobec których pragnie okazać się sprawiedliwy. Prowadzi go to nie tylko do poniechania szukania usprawiedliwienia przed Bogiem, ale także skazuje na wzajemne międzyludzkie oskarżenia i oceny. Tak rodzi się nowy rodzaj bezbożności. Samo zjawisko bezbożności nie jest dla chrześcijan niczym nowym. Byli oni z nią konfrontowani także w innych epokach, także w okresie reformacji, kiedy to właśnie przesłanie o usprawiedliwieniu przyniosło nowe duchowe siły i prowadziło do odnowienia Kościoła i uwolnienia chrześcijan do życia we wspólnocie. Jednak współczesna bezbożność ma swój wyróżnik. Jest nim brak oczywistości odniesienia do Boga oraz uznania prawdy, że człowiek pozostaje jego stworzeniem. To powoduje, że zwiastowanie Ewangelii o usprawiedliwieniu także w Kościołach budzi zakłopotanie, niezależnie od tego, czy przekazywane jest za pomocą tradycyjnych terminów takich jak ,grzech”

um die Kontextualität der Rechtfertigungslehre. Implikationen der Rechtfertigung in den Kontexten der Welt, tamże, s. 169-174. 
i „łaska”, czy też podejmowane są próby oddania go w inny sposób. Mimo tych trudności, założeniem nauki o usprawiedliwieniu nadal pozostaje spotkanie Boga z człowiekiem. Czy zatem w tak zarysowanych realiach współczesności jest możliwe zwiastowanie przesłania usprawiedliwienia przed Bogiem? Tak postawiwszy pytanie, autorzy dokumentu dają na nie jednoznaczną odpowiedź twierdzącą, wskazując, że niezależnie od samooceny rzeczywistości przez człowieka, jest on częścią Bożej rzeczywistości, w której doświadcza Bożego dobra, jak i gniewu. Bożą odpowiedzią w tej sytuacji jest wysłanie Jezusa Chrystusa - dawcy życia, który przychodzi do świat, nie pytając, czy ten Go rozpoznaje, wyznaje i czci. ${ }^{9}$

Część druga rozwija myśl o Bożej odpowiedzi na bezbożność w Chrystusie. Podkreśla ona, że ratujący czyn Boży w Chrystusie, Jego śmierci krzyżowej i zmartwychwstaniu, dokonany został w celu usprawiedliwienia bezbożnych, którzy w Bogu nie widzą swego Stwórcy, a usprawiedliwienia szukają wyłącznie w sobie. Tylko Chrystus jest w stanie wyrwać człowieka z jego bezbożności. Posłanie usprawiedliwienia, zakorzenione w słowach i czynach Jezusa z Nazaretu, spotkaniach apostołów ze zmartwychwstałym Panem, które przez nich zostało poniesione w świat mocą Ducha Świętego, dostarcza człowiekowi diagnozy jego sytuacji. Nie musi on wcześniej wiedzieć o swojej bezbożności. To w tym posłaniu człowiek rozpoznaje swe zagubienie przed Bogiem, a zarazem słyszy dobrą nowinę o ratunku w Bożej obietnicy odpuszczenia grzechów. Kierowana jest ona do grzeszników, co poświadczają teksty ewangeliczne mówiące o tym, że Chrystus, spożywając posiłki z grzesznikami, dał praktyczny dowód tego, że Bóg nie przebywa wyłącznie ze świętymi. Autorzy dokumentu podkreślają, że przesłanie o usprawiedliwieniu grzeszników stanowi także klucz do całości przesłania Starego i Nowego Testamentu. Jest to centralna treść Pisma Świętego, nawet jeśli na jego kartach bywa wyrażana także na inne sposoby. Reformacyjna ocena, że artykuł o usprawiedliwieniu sola gratia, sola fide stanowi articulus stantis et cadentis ecclesiae nie jest jednak tylko

9 Rechtfertigung heute, s. 524n., nr 1-4. 
wyborem określonej terminologii opisu zbawczego czynu Boga, ale także oddaniem Bogu czci za Jego zbawcze dzieło. Zachowanie przesłania o usprawiedliwieniu także dzisiaj stanowi kryterium istnienia Kościoła. Jednak sprowadzenie wierności temu artykułowi do skupienia się na określonych terminach teologicznych kosztem czynu Chrystusa stanowi, w ocenie autorów dokumentu, zdradę. Część drugą dokumentu kończy wezwanie do pokuty tych spośród Kościołów, w których doszło do wypaczenia przesłania o usprawiedliwieniu w wieść o samousprawiedliwieniu. ${ }^{10}$

Po takim zarysowaniu diagnozy współczesnej sytuacji oraz znaczenia i wagi odpowiedzi w Chrystusie ujętej w posłaniu o usprawiedliwieniu, w części trzeciej autorzy przechodzą do pytania, jak panowanie Chrystusa obejmuje człowieka. Kluczowym terminem jest tutaj wiara. To ona tworzy Kościół, a panowanie Chrystusa jest skuteczne i tworzy nową ludzkość. Wiara, a z nią panowanie Chrystusa, urzeczywistnia się w słuchaniu i przyjęciu Jego słowa. Nie zostało ono jednak zdeponowane na ziemi $\mathrm{w}$ jakiejś określonej hierarchii czy Kościele. Podobnie jak człowiek nie jest określany przez swoją sprawiedliwość, tak też Kościół nie jest określany przez własne wysiłki. Określa go Chrystus jako własne ciało. Dzięki Jego obecności w Duchu Świętym członkowie tego ciała mogą zostać przyjęci przez Boga. Są zatem zdani na pewność Bożego miłosierdzia w działaniu, a nie na siebie. Podstawowym sposobem zapośredniczenia zbawczego czynu Chrystusa dla człowieka jest chrzest. W nim bowiem Bóg staje się Bogiem nie oddalonym a bliskim, starego człowieka zastępuje nowy człowiek, narodzony z wody i z Ducha. $Z$ tej konstatacji autorzy dokumentu wyciągają konsekwencję praktyczną, pytając, czy członkowie Kościołów z właściwą powagą podchodzą do chrztu, a co za tym idzie do nauczania i zachowywania we wspólnocie świętych tych, którzy zostali ochrzczeni jako niemowlęta. ${ }^{11}$

Część czwarta dokumentu koncentruje się na międzyludzkich konsekwencjach działania środków łaski - zwiastowanego Słowa

10 Tamże, s. 525n., nr 5-8.

11 Tami̇e, s. 526, nr 9n. 
i sakramentów. Tworzą one nową międzyludzką wspólnotę, w której nie obowiązują rasowe czy narodowe podziały. Tym samym w Chrystusie przezwyciężone zostały nie tylko międzyludzkie podziały, ale i ludzka samotność. Pokój udzielony nowej ludzkości, chroniony we wspólnocie z Chrystusem, wzywa ludzi i narody do pojednania. Tak wyglądają wspólnotowe konsekwencje usprawiedliwienia. Autorzy sprzeciwiają się redukcji przesłania o usprawiedliwieniu jedynie do relacji jednostka - Bóg. Zawarta w nim odnowa obejmuje całe stworzenie. W tym planie dla stworzenia szczególne miejsce ma Kościół, w którym człowiekowi przyrzeczone zostaje usprawiedliwienie. To pociąga za sobą zobowiązanie, do pojmowania Kościoła nie jako oddzielonej od świata i zamkniętej na świat wspólnoty samousprawiedliwionych, ale jako wspólnoty grzeszników, którzy otrzymali usprawiedliwienie, by dać się posłać w świat, by służyć światu, naśladując Chrystusa, by tak jak On jeść i pić z grzesznikami. To zobowiązanie jest aktualne nawet wtedy, gdy świat odrzuca tę służbę członków Kościoła. Ten sprzeciw łączy się z gotowością Kościoła do poniesienia ofiary, która gwarantuje, że pozostaje on prawdziwym Kościołem Jezusa Chrystusa. Zamykając się przed światem jako krąg sprawiedliwych, Kościół wypacza przesłanie o usprawiedliwieniu i staje się sektą, gdyż neguje tym samym, że przesłanie o usprawiedliwieniu adresowane jest do chrześcijan i niechrześcijan. Środki łaski przekazane Kościołowi są mu zatem powierzone, by służył nimi zarówno wewnątrz swojej wspólnoty jak i na zewnątrz. ${ }^{12}$

Po opisaniu wspólnotowego wymiaru usprawiedliwienia autorzy dokumentu w części piątej przystępują do charakterystyki nowego życia usprawiedliwionych. Widzą je jako życie w mocy zmartwychwstania. Podkreślają, że wiara chrześcijan musi mieć widoczne dla innych konsekwencje, tak jak to już było niejednokrotnie w historii chrześcijaństwa. Ich brak pozostaje poważnym pytaniem dla współczesnych Kościołów. Wytłumaczeniem nie może tutaj być twierdzenie, że czyny Bożej miłości dokonują się w ciszy i ukryciu, gdyż doświadczenie przez ludzi Bożej miłości rozświetla mroki świata

12 Tamże, s. 527, nr 11-15. 
i pozwala pytać o swoje źródło. Autorzy wracają tutaj do chrztu, w którym człowiek zostaje przyjęty w śmierć i zmartwychwstanie Chrystusa. Krytycznie zauważają, że myśl o zmartwychwstaniu została w luterańskim myśleniu zepchnięta na dalszy plan przez centralność wieści o krzyżu Chrystusa. Podkreślają jednak, że ten skutek chrztu nie może być pomijany. Musi działać kształtująco na życie chrześcijan. Moce zmartwychwstania działają w życiu i śmierci ochrzczonych, powinny skutkować w naśladowaniu Chrystusa, także w Jego śmierci i zmartwychwstaniu, a więc straceniu własnego życia, by zyskać Chrystusa. Autorzy dokumentu pytają, czy nie jest aby wypaczeniem życia z chrztu, kiedy chrześcijanie wybierają drogę wyłącznie sukcesu, widząc w krzyżu dowód klęski. Naśladowanie Chrystusa w Jego życiu nie da się oddzielić od naśladowania Go w Jego śmierci. Takie pomijanie naśladowania Chrystusa w Jego śmierci neguje uzasadnienie nowego życia chrześcijan w mocy zmartwychwstania i może być powodem niepewności ich drogi w świecie. Brak ofiarnej miłości w życiu chrześcijan jest podstawą wielorakiej krytyki Kościoła, który wydaje się nie tym, czym być powinien. Negowany, jako znak sukcesu, krzyż dzięki zmartwychwstaniu stał się znakiem zwycięstwa dla tych, którzy oddali swoje życie jako świadectwo Chrystusa i Jego przyszłości. Jednak z mocy zmartwychwstania nie wynikają zewnętrzne siły przeciw mocom tego świata. Narzędzia walki z nimi dostępne Kościołowi są duchowe: słowo, modlitwa, czyn miłości, cierpienie. Te środki przyznał Bóg Kościołowi jako jego udział w rządzeniu światem. Brak rezygnacji ze środków zewnętrznej władzy prowadzi niejednokrotnie do konfliktów na linii państwo - Kościół i odbiera Kościołowi pełnomocnictwo do stawania przeciw każdej politycznej przemocy kierowanej przeciw prawdziwej ludzkiej wspólnocie. ${ }^{13}$

Ostatnia część poświęcona jest znaczeniu usprawiedliwienia jako podstawy odwagi do życia w świecie przepełnionym demonicznymi siłami i pokusami. Wśród nich autorzy wymieniają m.in.: wzrastający nacjonalizm, kolektywny ogląd świata, demokratyczna wiara

13 Tamże, s. 527-529, nr 16-24. 
w postęp, materializm społeczeństw dobrobytu. Chrzest pozwala odkryć, że Bóg utrzymuje świat, także za pośrednictwem złych, a Jego moc potwierdza się także w tym, że pozwala, by Jego dzieło dokonało się przez ręce tych, którzy zaprzeczają Jego istnieniu lub Go nienawidzą. Usprawiedliwienie obdarza chrześcijan odwagą do życia pod panowaniem Bożym i pozwala im czynić dobro we współpracy z tymi, którzy czynią je dla własnej, a nie Bożej chwały. Wiara pozwala przezwyciężyć bezsensowność napadającą człowieka w jego pracy. Pozwala na przekonanie o Bożym działaniu w świecie, nawet gdy nie jest to rozpoznawalne. Co z tym idzie, usprawiedliwienie jest także źródłem odwagi, gdy konieczne jest zaryzykowanie swojego życia. Chrześcijanin niesie w sobie zobowiązanie, by nowe człowieczeństwo, dane światu w śmierci i zmartwychwstaniu Chrystusa, przez niego zyskało swą postać. Jego życie nie jest życiem dla własnej chwały, gdyż usprawiedliwiający Boży wyrok daje się przyjąć tylko w nieustającej pokucie. Ma to także swoje znaczenie dla Kościoła, który pozostaje przez to uwolniony od presji tego, by mieć zawsze słuszność. W obliczu blaknących nadziei ludzkości i faktu, że kolejne ludzkie poszukiwania nowej radości życia okazują się iluzją, chrześcijanie w Chrystusie mogą dać światu nową nadzieję. Chrystus, obecny wśród chrześcijan, jest ich ochroną w świecie, jest ich ratunkiem na sądzie, a także nadzieją, aż po wieczność. ${ }^{14}$

\section{Usprawiedliwienie i różne konteksty w świecie}

Dokument Controversy regarding the Contextuality of the Doctrine of Justification. The implications of justification in the world's contexts stanowi pewnego rodzaju krótkie podsumowanie tematyki poruszanej na konsultacji poświęconej usprawiedliwieniu, jaka odbyła się w 1998 r. w Wittenberdze. Otwiera go stosunkowo obszerna przedmowa, która poprzedza omówienie implikacji nauki o usprawiedliwieniu dla różnych kontekstów od globalnej ekonomii po Kościół, całość zamyka wniosek końcowy.

14 Tamże, s. 529, nr 25-28. 
Przedmowa zajmuje się nauką o usprawiedliwieniu jako taką. Wskazuje na nierozerwalny związek dobrej nowiny o usprawiedliwieniu z doświadczeniem człowieka, który zostaje zbawiony nie na podstawie uczynków, ale jedynie przez wiarę ze względu na zasługę Chrystusa. Wiara - dar Ducha Świętego - jest odpowiedzią na usłyszaną dobrą nowinę. Dzięki niej człowiek otrzymuje Chrystusa, by żyć w Nim i tym samym otrzymać życie zabezpieczone w Bogu. Ewangelia uwalnia spod presji wymagań Zakonu, człowiek nie musi czynić nic w celu swojego zbawienia. Dzięki temu może w wolności i miłości żyć bardziej satysfakcjonującym życiem i być zdolnym do wykonywania Zakonu w duchu Jezusa Chrystusa. Powyższe podsumowanie treści nauki o usprawiedliwieniu autorzy dokumentu widzą jako powtórzenie kluczowego przesłania luterańskiej tradycji. Zadaniem refleksji podejmowanej w czasie konsultacji w Wittenberdze było nie tyle zgłębianie ściśle teologicznych pytań powiązanych ze współczesnym spojrzeniem na ten element teologicznego dziedzictwa, ile odniesienie go do konkretnych obszarów ludzkiego życia i poszukiwanie implikacji nauki o usprawiedliwieniu dla tego, jak chrześcijańska wolność jest przeżywana na ich obszarach. Wskazano przy tym, że przesłanie o usprawiedliwieniu jest adresowane do wszystkich, mimo tego, że niejednokrotnie przesłonięte jest przez inne popularne przesłania i systemy, które jednak obciążają życie człowieka niepokojem, wątpliwościami, bezcelowością, a także potrzebą samousprawiedliwienia względem innych ludzi. Zwrócono przy tym uwagę, że kiedyś przesłanie o usprawiedliwieniu wyzwalało od zniewolenia systemem religijnym. Dziś nie tylko systemy religijne zachowały potencjał niewolenia człowieka. Oprócz nich taką zdolność mają ogromne i skomplikowane systemy ekonomiczne, komunikacyjne oraz ideologiczne. Wszystkie one niszczą jednostkową i wspólnotową integralność ludzkich bytów i świata. ${ }^{15}$

Pierwszym z kontekstów, do jakich przesłanie o usprawiedliwieniu odnieśli autorzy dokumentu, jest globalna ekonomia. Krytycznie wskazują na dominację neoliberalnej ideologii zwiastującej

${ }_{15}$ Controversy regarding the Contextuality, s. 181n. 
usprawiedliwienie przez produkcję, prosperity i konsumpcję. „Rynek" stał się tym, który usprawiedliwia i potępia, oczekuje od ludzi i narodów dostosowania się do jego wymagań, rabując je z ich godności i autonomii. W odpowiedzi na tę diagnozę autorzy wskazują, że nauka o usprawiedliwieniu sprzeciwia się warunkowaniu godności osoby przez okoliczności natury ekonomicznej. Przesłanie usprawiedliwienia zakład, ich zdaniem, że uwolniony z ideologicznej stronniczości system ekonomiczny może być kierowany w stronę procesów dających większe pole współudziału. Z usprawiedliwienia wynika życie w miłości do Boga i bliźnich, co przekłada się na ich wzajemne uznanie $\mathrm{w}$ ramach lokalnych i globalnych struktur. W praktyce przesłanie usprawiedliwienia w kontekście ekonomicznym oznacza np. to, że nie można żądać od krajów rozwijających się, by dostosowały się po prostu do wolnego rynku. To, czy dany kraj spełnia pokładane w nim oczekiwania, zależy od tego, czy generuje większą sprawiedliwość społeczną w ramach działań rynkowych. Usprawiedliwienie tworzy podstawę do głębszego dialogu międzyludzkiego (Północy i Południa, a także Południa i Południa), tak by w rzeczywistości ekonomicznej wprowadzane były do bardziej sprawiedliwego życia i handlu. Usprawiedliwienie w kontekście ekonomicznym oznacza praktycznie także: opowiadanie się za ofiarami tyranii rynku, które pozbawiane są nie tylko zasobów naturalnych, ale i ludzkiej godności, która powinna być nienaruszalna; zrównoważoną ekonomię, która szanuje ziemię i sprzeciwia się ukierunkowaniu jedynie na maksymalizowanie zysku mniejszości; odrzucenie „religii produktywności”. Usprawiedliwienie stawia nad wszelką ekonomią Bożą oikonomię, która rozwija miłosierdzie i sprawiedliwość. ${ }^{16}$

Kolejnym kontekstem, jaki znalazł się w obszarze zainteresowania autorów dokumentu, jest globalna komunikacja. Wskazują oni na wzrastające znaczenie globalnych systemów komunikacyjnych kreujących społeczeństwa oparte na informacji, z którymi wiązana jest obietnica przemienienia ludzkości w bardziej harmonijną wspólnotę równych ludzi. Możliwości tych systemów są docenione o tyle, o ile

16 Tamże, s. 182n., nr 1-3. 
faktycznie umożliwiają poprawę komunikacji. W takim zakresie powinny z nich też korzystać Kościoły, by przekazywać przesłanie usprawiedliwienia. Jednak z perspektywy usprawiedliwienia widać także niebezpieczeństwa związane z rozwojem globalnych systemów komunikacyjnych: nierówny dostęp do systemów komunikacji; dominacja Zachodu prowadząca do neokolonizacji innych kultur; potencjał technologii informacyjnej dzielenia ludzi; brak jasnych granic między faktami, opiniami, wiedzą i rozumieniem. W obliczu tych zagrożeń usprawiedliwienie wzywa do sprzeciwu wobec mesjanistycznych obietnic masowych systemów komunikacji i skupienie się na polepszaniu prawdziwej społeczności. ${ }^{17}$

Trzecim z kontekstów do których odniesiono naukę o usprawiedliwieniu są kwestie specyficzne dla różnych płci. Rozważania na ten temat rozpoczęto od wskazania na bezwarunkową Bożą miłość do każdego człowieka, która obejmuje troskę o potrzeby materialne, jak i duchowe. W tym kontekście przesłanie o usprawiedliwieniu podkreśla równą wartość kobiet i mężczyzn, a co za tym idzie domaga się zastąpienia stereotypów i generalizacji na temat relacji obu płci wrażliwym rozumieniem uwarunkowań życia obu z nich. Wskazano także, że jest ona motywacją do szkolenia kobiecych liderek, by wszystkie grupy globalnej społeczność zyskały głos w Kościele i społeczeństwie. Zaznaczono także, że na gruncie nauki o usprawiedliwieniu powstaje identyfikacja grzechu jako samousprawiedliwienia. Mimo trafności takiej identyfikacji należy brać także pod uwagę, że nie jest ona częścią doświadczenia wielu kobiet, których umiejscowienie w patriarchalnym społeczeństwie prowadzi nie do samousprawiedliwienia ale samoumniejszenia i rezygnacji z inwestycji w siebie. Usprawiedliwienie nie pozwala na trywializację siebie i stawia wyzwanie systemom, które prowadzą do pozbawiania ludzi szacunku, czy też uniemożliwiają korzystanie w pełni z życia, które przysługuje im jako umiłowanym przez Boga. Zatem usprawiedliwienie domaga

17 Tamże, s. 183, nr 4. 
się słuchania także głosów kobiet, tak by uwalniająca miłość Boga mogła być konkretnie zwiastowana. ${ }^{18}$

Kolejna część omawianego dokumentu poświęcona jest kontekstowi pluralizmu. Wskazano w niej, że Chrystus jest obecny i zapośredniczony w Ewangelii i sakramentach. Wierzący są zobowiązany do ciągłej interpretacji tego faktu zgodnie z gramatyką swojej wiary, gdyż zgodnie z nauką o usprawiedliwieniu ich sprawiedliwość jest oparta na Chrystusie, a nie na nierozerwalnym związku z określonymi formami przekazywania wiary. Wierzący ciągle nie w pełni pojmują Chrystusa, przy czym ich wiara w Niego, jako ratującego ludzkość, pozostaje centralna. Fakt ten pozwala im z otwartością rozumieć ludzi innych religii i przekonań, akceptować ich w miłości Chrystusa i zwracać się ku nim z przepełnionym miłością świadectwem. Usprawiedliwienie pozwala na gotowość przyjęcia w dialogu z przedstawicielami innych religii tego, co zgadza się z chrześcijańskim zrozumieniem, a także je transcenduje, bez narażania na szwank istotnych chrześcijańskich przekonań. Przesłanie o usprawiedliwieniu wskazuje w kontekście pluralizmu na uniwersalizm łaski. Ten fakt powołuje usprawiedliwionych do akceptującej solidarności jako formy świadectwa wobec innych. Solidarność jest tutaj rozumiana jako głęboka przyjaźń i dostępność dla innych. Usprawiedliwiony Kościół będzie odnosił się do biedy w każdym kontekście. Solidarność oznacza świadectwo Chrystusa w cierpieniu z innymi, także przedstawicielami innych religii, zamiast dążenia do zdominowania ich chrześcijańskim przesłaniem i czynami. W omówieniu kontekstu pluralizmu pojawia się także pojęcie sekularyzacji. Dostrzeżono w niej element pluralistycznego świata, a także potencjał do wzmocnienia wolności i solidarności. Jednocześnie odniesienie do przesłania o usprawiedliwieniu stawia wyzwanie naruszeniom ludzkiej godności wynikającym z sekularystycznego stylu myślenia prowadzącego do braku miłosierdzia. Rozwijając to odniesienie do sekularyzmu, wskazano na współczesny przymus stałego usprawiedliwiania swojego istnienia, które czyni ludzi oskarżającymi i oskarżonymi. Przesłanie

18 Tamże, s. 183n., nr 5n. 
o usprawiedliwieniu w Chrystusie uwalnia od tego przymusu, a także obdarza prawdą życia uwalniającą od jego kłamstw. Usprawiedliwieni grzesznicy nie muszą brać udziału w patologicznym poszukiwaniu kozłów ofiarnych. Świadomość pluralizmu kontekstu zobowiązuje do adekwatnego wyrażania przesłania o usprawiedliwieniu, które unika sformułowań naiwnych w sekularystycznym kontekście czy też obcych w danym kontekście religijnym. ${ }^{19}$

Następnym kontekstem, do którego autorzy dokumentu odnoszą naukę o usprawiedliwieniu, są złe moce. Chodzi tutaj o anonimowe i ,ponadnaturalne" moce, które, jak tyrani, trzymają ludzi spętanych. Przykładem takich mocy mogą być w specyficznych warunkach wskazane wyżej moce socjoekonomiczne i socjopolityczne. Zadaniem chrześcijan jest przetłumaczenie na struktury polityczne i gospodarcze tego, co Luter nazywał „wałami przeciw grzechowi”, a także zwrócenie się w osobistej trosce ku człowiekowi i zapewnienie duchowego wsparcia. Chrześcijanie w całej swojej egzystencji życia z prawdy Jezusa Chrystusa, zaś Kościół jako Jego ciało, realizują się w wielości zadań i posług, które mają za zadanie budować i przeciwdziałać złu. ${ }^{20}$

Właśnie Kościół stał się ostatnim z kontekstów, w jakim rozważono implikacje usprawiedliwienia. Uznano go za konsekwencję usprawiedliwienia. Kościół jako wielkość społeczna, tak samo jak jego indywidualni członkowie, musi powracać do swojej tożsamości usprawiedliwionego. Pewność usprawiedliwienia uzdalnia go do profetycznego świadectwa i uwalnia od konieczności imitowania kulturowych kryteriów sukcesu. Chrześcijańska wolność wynikająca z usprawiedliwienia to także wolność uznania własnej winy, dlatego Kościół może przyjmować swoje winy i porażki bez nieustannego przyjmowania obronnej postawy. Dzięki usprawiedliwieniu Kościół jest też zdolny do traktowania zarówno swoich członków, jak i innych ludzi, z radosną łaskawością i dawania miejsca w swoim codziennym i liturgicznym życiu odczuwalnym doświadczeniom

19 Tamże, s. 184n., nr 7-9.

20 Tamże, s. 185, nr 10. 
łaski; uwolnienia się od presji przyprowadzenia ludzi z powrotem do Kościoła i podjęcia refleksji nad przekonującą formą własnego świadectwa; nieusprawiedliwiania siebie nawet za pomocą własnej nauki o usprawiedliwieniu, ale do poświęcenia się przekazywaniu usprawiedliwienia całemu światu. Kościół, dzięki usprawiedliwieniu, może być przesłaniem o usprawiedliwieniu i manifestacją łaski. ${ }^{21}$

Omawiany dokument zamyka wniosek końcowy zatytułowany: Usprawiedliwienie wezwaniem do apostolskiego świadectwa. Odwołuje się on do reformacji jako ruchu odnowienia, którego istotą nie było propagowanie doktryny, ale rozświetlenie życia ludzi światłem Ducha Świętego, tak by ich wzmocnić, nakarmić i zmotywować do dzielenia się otrzymanymi darami. Reformacyjne przesłanie o usprawiedliwieniu w sposób unikalny łączyło kontekst jednostek i społeczeństw wyzwolonych do pełnej i samodzielnej odpowiedzialności we wspólnocie. Bóg, w swej bezwarunkowej miłości do człowieka i świata, umożliwia zmianę i uzdalnia do przepełnionego miłością działania. Wyznanie chrześcijańskiej wiary zapewnia, że żadna moc nie może zwyciężyć usprawiedliwionych przez Boga. Realizuje się to w doświadczaniu zaufania Chrystusowi. Boża miłość uwalnia do miłości bliźniego i nieinstrumentalizowania go w imię ideologii, a także do propagowania sprawiedliwości wobec jednostek i struktur, tak by nie powstawały nowe niesprawiedliwe relacje. W tym kontekście centralną implikacją usprawiedliwienia są prawa człowieka, gdyż bezwarunkowa miłość Boga chce się realizować w osobistych, społecznych i politycznych sferach życia. Wiara w usprawiedliwienie pozwala przy tym oddzielać sferę działania ludzkiego i boskiego. Usprawiedliwieni mogą łączyć uwielbienie Boga ze służbą światu w nabożeństwie, modlitwie i diakonii. Usprawiedliwieni słuchają Bożego słowa i są powołani na Bożych współpracowników. Wypełniając powierzoną im apostolską misję, antycypują w sposób konkretny to, co przyobiecane jest w chwale w Trójjedynego Boga. Autorzy podsumowują, że wysiłki te mogą wydawać się nie tylko niewystarczające, ale nawet stojące na przegranej pozycji. To wrażenie jednak

${ }^{21}$ Tamże, s. 185, nr 11. 
nie unieważnia ważkości usprawiedliwienia dla wielu kontekstów świata, a także nie pozbawia usprawiedliwionych chęci partycypowania w Bożych działaniach w świecie. ${ }^{22}$

\section{Dwie metody aktualizacji XVI-wiecznego articulus stantis et cadentis Ecclesiae}

W zaprezentowanych wyżej dwóch dokumentach ŚFL podjęto dwojaką próbę aktualizacji nauki o usprawiedliwieniu. Każda z nich jest jednak głęboko zakorzeniona w reformacyjnej tradycji.

Pierwszy z omówionych dokumentów stara się opisać wydarzenie usprawiedliwienia w życiu człowieka, które dokonuje się w spotkaniu z Bogiem dzięki zbawczemu czynowi Jezusa Chrystusa. Stara się to czynić językiem współczesnym, a jednocześnie jest to perspektywa charakterystyczna dla tak klasycznych ujęć nauki o usprawiedliwieniu jak traktat Marcina Lutra z 1520 r. O wolności chrześcijanina. Przyjmując za punkt wyjścia indywidualną perspektywę usprawiedliwienia, dokument z Helsinek nie zapomina o tym, że Lutrowy traktat zawiera w sobie fundamentalne wezwanie do służby bliźniemu W miłości. ${ }^{23}$ Dokument przekłada ten reformacyjny topos na kategorię świadectwa chrześcijan w świecie, wskazując, że to właśnie miłość i służba względem bliźnich zapewniają wiarygodność chrześcijańskiemu przesłaniu. Zatem doświadczenie usprawiedliwienia powinno nieść za sobą konsekwencje w życiu usprawiedliwionych. Wolność, jaką uzyskują oni dzięki usprawiedliwieniu ze względu na Chrystusa, od konieczności podejmowania wysiłków na rzecz usprawiedliwienia się przed sobą i światem mogą spożytkować na naśladowanie Chrystusa. Ta aktywność chrześcijan w świecie ma się przekładać nie tylko na ich indywidualne doświadczenie solidarności z grzesznikami, ale

22 Tamże, s. 185n., nr 12.

23 M. L u t e r, Von der Freiheit eines Christenmenschen (1520), w: D. Martin Luthers Werke. Kritische Gesamtausgabe, t. 7, Weimar 1897, s. 20-38 (wyd. pol. M. L u t e r, O wolności chrześcijanina, tłum. M. C z y ż, w: t e n ż e, Pisma etyczne, Bielsko-Biała 2009, s. 28-53). 
także na współpracę z tymi wszystkimi, którzy w pluralistycznym świecie pracują na rzecz dobra innych, na zaangażowanie w pojednanie między narodami czy rasami, czy na właściwe stosunki na linii państwo - Kościół, zachowujące odpowiednie pryncypia rozdziału, dające Kościołowi pole do niezależnej, wiarygodnej, profetycznej krytyki.

Drugi z dokumentów przyjmuje inną metodę aktualizacji. Skupia się na charakterystycznym ujęciu nauki o usprawiedliwieniu jako podstawowego narzędzia hermeneutycznego luterańskiej reformacji. Jego zastosowanie widać znakomicie w teologicznym testamencie Marcina Lutra - Artykułach szmalkaldzkich, w których drugiej części artykuł o usprawiedliwieniu posłużył za krytyczne narzędzie oceny różnych kościelnych praktyk odrzuconych przez reformację. ${ }^{24}$ Podobne wyzwanie podejmują autorzy dokumentu przygotowanego podczas konsultacji w Wittenberdze. Dla nich nauka o usprawiedliwieniu staje się narzędziem krytycznym, skutecznym w ocenie treści nie tylko kościelno-teologicznych (choć te także zostają poddane ocenie np. w rozdziale poświęconym Kościołowi), ale również dla ogólnej oceny stosunków panujących w świecie. Pryncypia formułowane w nauce o usprawiedliwieniu stają się więc punktem wyjścia do krytycznej oceny dominujących poglądów i praktyk ekonomicznych, globalnych systemów komunikacyjnych, spraw związanych z różnicami płci, a także funkcjonowania chrześcijan w pluralistycznym społeczeństwie. Ta interpretacja usprawiedliwienia pozwala przekroczyć jednostkową perspektywę i dostrzec, że wśród mocy pętających człowieka są nie tylko jego pragnienie samousprawiedliwienia, ale różnego rodzaju strukturalne, anonimowe, systemowe siły. Nauka o usprawiedliwieniu daje narzędzia, by je nazwać i zidentyfikować.

24 Artikel christlicher Lehre so da hätten pollen aufs Concilium zu Mantua oder wo es sonst worden wäre überantwort werden von unsers Teils wegen und was wir annehmen oder nachgeben kunnten oder nicht etc. Durch Dokt. Martin Luther geschrieben. Anno 1537, w: I. D i n g e 1 i in. (red.), Die Bekenntnisschriften der Evangelisch-Lutherischen Kirche. Vollständige Neuedition, Göttingen 2014, s. 236-709, (wyd. pol. Artykuty szmalkaldzkie z 1537, tłum. W. N i e m c z y k, w: Księgi Wyznaniowe Kościoła Luterańskiego, Bielsko-Biała 2003, s. 335-358). 
Podobnie jednak jak w hermeneutycznych wysiłkach stosowania nauki o usprawiedliwieniu stosownej do oceny sytuacji teologiczno-kościelnej doby reformacji, koniec końców autorom współczesnego dokumentu chodzi o zaangażowanie chrześcijan na rzecz treści nauki o usprawiedliwieniu, ich osobiste doświadczenie usprawiedliwienia w Chrystusie, które daje wolność do służby bliźniemu w miłości oraz apostolskim świadectwie wobec świata.

Jerzy SOJKA 